\title{
The construction and prospect of China National Bibliography ${ }^{1}$
}

\author{
Xi Yang $\triangleleft$, Lingyun Gao, Yunqin Zhu
}

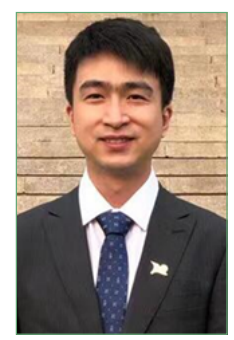

Yang Xi,

Chinese Acquistions \& Cataloging Department, National Library of China, Zhongguancun str., 33, Hai Dian District, 100081, Beijing, China,

MA, assistant professor

ORCID: 0000-0002-6624-6594 e-mail:yangxi@nlc.cn

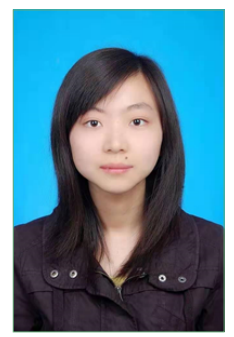

Gao Lingyun,

Chinese Acquistions \& Cataloging Department, National Library of China, Zhongguancun str., 33, Hai Dian District, 100081, Beijing, China,

MA

ORCID: 0000-0001-8314-8198 e-mail:lingyun236@126.com



Zhu Yunqin,

Chinese Acquistions \& Cataloging Department, National Library of China, Zhongguancun str., 33, Hai Dian District, 100081, Beijing, China,

MA

ORCID: 0000-0002-5497-7330 e-mail: zhu_yunqin@126.com

Abstract. The national bibliography is a comprehensive and systematic catalog that gathers and records the information of all the publications in a country, and serves as the base for monitoring and managing all the information related. China National Bibliography in modern times has been continuously developed and improved, thanks to the legacies from its past and the experiences of other countries. The present paper first reviews the past and the present of China National Bibliography, then discusses the progress of researches on the application of Functional Requirements for Bibliographic Records (FRBR), and finally explains the survey on the feasibility of adopting the new cataloging standard RDA in China. Although the FRBRization of China National Bibliography, to a certain extent, facilitates the readers' use, we argue that the FRBRization of the existing MARC data cannot realize all the ideas FRBR creates. There are some problems, such as the distinctions between works and expressions, the construction issues of the bibliographic and authority data. In the process of implementing localized RDA in the cataloging of foreign materials of all languages and types, the National Library of China conducted an investigation into the feasibility of implementing RDA in the cataloging of Chinese literature, finding that although there is not a vast gulf between RDA and current Chinese cataloging standards, a lot of problems do need to be resolved both theoretically and practically. First, the Chinese national standard "Resource Description" of the day and the CNMARC standards need to be improved. Second, it is urgent to reduce the increasing manual workload of the catalogers caused by adopting RDA. Third, both the staff force and the system reserve ability of the member libraries under Online Library Cataloging Center of China should be taken into account. Fourth, RDA would add new data elements, thus the initiation of this new standard simultaneously requires updating and transforming the integrated library system. Last but not the least, the application of RDA also requires the development of corresponding online toolkits to improve the cataloging efficiency.

Keywords: China National Bibliography, FRBRization, Resource Description and Access (RDA)

Citation: Yang Xi, Gao L., Zhu Yu. The construction and prospect of China National Bibliography. Bibliosphere. 2021. № 2. P. 95-102. https://doi. org/10.20913/1815-3186-2021-2-95-102. 


\section{Создание и перспективы национальной библиографии в Китае}

\section{Си Ян $\triangleleft$, Линьюнь Гао, Юньцинь Чжу}

\author{
Ян Си, \\ Отдел комплектования \\ и каталогизации китайской \\ литературы, Национальная \\ библиотека Китая, \\ ул. Чжунгуаньцунь, 33, район \\ Хайдянь, 100081, Пекин, Китай, \\ Магистр, доцент \\ ORCID: 0000-0002-6624-6594 \\ e-mail:yangxi@nlc.cn
}

\author{
Гао Линьюнь, \\ Отдел комплектования \\ и каталогизации китайской \\ литературы, Национальная \\ библиотека Китая, \\ ул. Чжунгуаньцунь, 33, \\ район Хайдянь, 100081, Пекин, Китай, \\ Магистр
}

ORCID: 0000-0001-8314-8198 e-mail: lingyun236@126.com

\section{Чжу Юньцинь,}

Отдел комплектования

и каталогизации китайской литературы, Национальная библиотека Китая,

ул. Чжунгуаньцунь, 33,

район Хайдянь, 100081, Пекин, Китай, Магистр

ORCID: 0000-0002-5497-7330

e-mail:zhu_yunqin@126.com
Аннотация. Национальная библиография - это всеобъемлющий и систематизированный каталог, который содержит информацию обо всех публикациях в стране и служит основой для мониторинга и управления всей связанной с этим информацией. Китайская национальная библиография в наше время постоянно развивается и совершенствуется благодаря своему наследию и опыту других стран. В статье рассматривается прошлое и настоящее Национальной библиографии Китая, обсуждается ход исследований по применению функциональных требований к библиографическим записям (FRBR) и, наконец, объясняется целесообразность принятия нового стандарта каталогизации RDA в Китае. Хотя использование FRBR в Китайской национальной библиографии в определенной степени облегчает ее использование читателями, авторы утверждают, что использование FRBR в формате данных MARC не может реализовать все идеи, которые дает FRBR. Существуют некоторые проблемы, такие как различия между произведениями и выражениями, проблемы создания библиографических и авторитетных данных. В ходе внедрения локализованного RDA в каталогизацию иностранных материалов на всех языках и всех типов Национальная библиотека Китая провела исследование возможности внедрения RDA в каталогизацию китайской литературы и обнаружила, что, хотя между RDA и нынешними китайскими стандартами каталогизации не существует огромной разницы, необходимо решить множество проблем как теоретически, так и практически. Во-первых, необходимо усовершенствовать китайский национальный стандарт «Описание ресурсов» и стандарты CNMARC. Во-вторых, необходимо срочно сократить растущую ручную нагрузку на каталогизаторов, вызванную принятием RDA. B-третьих, следует учитывать как численность персонала, так и возможности системного резерва библиотек-членов Центра онлайн-каталогизации библиотек Китая. B-четвертых, RDA добавит новые элементы данных, поэтому введение этого нового стандарта одновременно требует обновления и преобразования интегрированной библиотечной системы. И последнее, но не менее важное: применение RDA также требует разработки соответствующих онлайновых наборов инструментов для повышения эффективности каталогизации.

Ключевые слова: Национальная библиография Китая, функциональные требования к библиографическим записям, описание ресурса и доступа к нему

Для цитирования: Ян Си, Гао Линьюнь, Чжу Юньцинь Создание и перспективы национальной библиографии в Китае // Библиосфера. 2021. № 2. C. 95-102. https://doi.org/10.20913/1815-3186-2021-2-95-102. 
Introduction. The construction of China National Bibliography in China

A bibliography is not only a summary of the literature, but also a tool for organizing, managing, promoting and utilizing it. The national bibliography is a record of both the past and the present conditions of all the publications in a country (Chen et al., 1984). With its long cultural history and abundant classical books, China has the tradition of compiling national bibliographies since the Han dynasty (206 $\mathrm{BC}-\mathrm{AD} 220$ ). The official bibliographies from the past provide an overview of all the Chinese ancient books. As the earliest bibliography compiled in a planned and organized manner, the book Hanshu Yiwenzhi, which was compiled in the Han dynasty, reflects all the existing literature at that time, and is regarded as a comprehensive catalog with the original form of a national bibliography. "Yiwenzhi" refers to the chronological catalog of historical books, political books and local chronicles of various dynasties in China.

After the Han dynasty (206 BC-AD 220), national bibliographies named by "Yiwenzhi" or "Jingjizhi", following the layouts of those in the book Hanshu Yiwenzhi, were compiled in almost all dynasties, the majority of which are official ones. Meanwhile, historians, bibliographers and bibliophiles all paid close attention to bibliographies. They inclined to use them for reading guidance as well as literature organization and propagation. Being appointed by the government or voluntarily, they led the compilation of many national bibliographies recording all the literature of a specific historical time (Huang, 1986). Among them, the compilation of the book Complete Library of the Four Treasuries in the Qing dynasty (1644-1911) is considered the pinnacle of official bibliographies in ancient China.

The characteristics of China National Bibliography in ancient times are as follows (Huang, 1986):

(1) The compilation and utilization of classified catalogs was valued. All the national bibliographies in ancient times are classified catalogs. The book $Q i$ Lue edited in the Han dynasty created the classification system of "one divides into six". The four-branch classification method was firstly used in the compilation of the book Suishu Jingjizhi in the Tang dynasty (618-907). Being used for thousands of years in China, up to now, this four-branch classification method has still been adopted in the cataloging of ancient books in most libraries and publishing units.

(2) The description of the content was highlighted. The ancient national bibliographies were not just satisfied with the description of external features, but focused on reflecting its internal subject content and academic value.

(3) As for the descriptive data, the role of the title entry for identifying the literature was emphasized. The bibliographies compiled by either officials or individuals used the title entry as the starting point for identifying the literature, because it served the function of revealing the content and the author. Each bibliography was recorded with the completeness and accuracy of all the title entries.

(4) The bibliographies were all retrospective ones in the form of books. The scope of the ancient national bibliographies was based on all the literature of a certain period, some of which spanned for several dynasties, while some others recorded only the works of one generation. These bibliographies, with their fine content and rigorous compilation, are important reference books for the study of Chinese history. They are all in the form of books, either as separate editions or multi-volume series.

After the founding of the People's Republic of China (P.R.C.), a retrospective bibliography on the Minguo period (1911-1949) was worked on. From the 1980s to the 1990s, the Beijing Library (now the National Library of China) compiled a set of General Bibliography on the Minguo Period, which mainly included the Chinese Minguo books collected in the Beijing Library, Shanghai Library, and Chongqing Library, supplemented by some collected in other libraries. This bibliography provides a general picture of the publication of books during the Minguo period, and reflects the development of history, culture, education, economy and society of that time.

In view of the fact that the Minguo documents are getting aging, damaged or even ruined, the Minguo Documents Preservation and Conservation Program was initiated by the National Library of China (NLC) in 2012. This program carried out a general survey of the Minguo documents, to get the basic information of the collection status of the Minguo documents in libraries throughout China. Relying on the Online Library Cataloging Center (OLCC) of China, the bibliographic data of the Minguo documents uploaded by the Minguo documents preservation pilot units was gathered, revised and installed into the Union Cata$\log$ of Minguo Documents platform. At present, the platform has collected nearly 300,000 items of bibliographic data and more than 500,000 items of collection data from the NLC and some local libraries. Based on it, the NLC began to organize the compilation of a new edition of General Bibliography on the Minguo Period.

This new edition of general bibliography will be greatly improved than the previous one, in terms of document numbers, document types, completeness of bibliographic data, representativeness of the collection institutions, arrangement of the content, etc. (National..., 2020). After the publication of all volumes, a dynamic data association would be conducted between the data in the new general bibliography and the online data of the Union Cata$\log$ of Minguo Documents platform, so as to meet the needs of the readers in the digital era, to search, identify, select and obtain the data of the Minguo documents conveniently and in real-time terms. 
In addition to the bibliography on the Minguo period, one for modern times was taken into account after the founding of the People's Republic of China (P.R.C.) in 1949. Since then, the book National Register of Books of China had been born, which was a kind of national bibliography. In 1987, China National Bibliography (1985) was published, which was the first bibliography in China to be officially named after "National Bibliography" with the true significance of a national bibliography. The annually printed version of China National Bibliography ceased to be published in 1994, due to the advent of machine-readable databases. In October 1997, the OLCC of China was established, and its Union Catalog played the role of the national bibliography to a certain extent. By the end of 2020, the total number of Chinese and foreign languages data in the Union Catalog had reached 14.27 million items, of which 10.08 million items are Chinese bibliographic data, including that of books, periodicals, newspapers, dissertations, audio-visual materials, electronic resources, microforms, etc., and 4.19 million items are foreign bibliographic data, covering materials in more than 80 languages. There are 1.81 million items of name authority data and 120,000 items of subject authority data.

The NLC planned to restart the China National Bibliography Program in 2010, with the aim to boost the service of China National Bibliography in the digital age, to fully integrate bibliographic resources, timely report the latest achievements of cultural construction, and comprehensively display the development of China in such areas as politics, economy, culture, and technology from the viewpoint of publishing conditions. Relying on the Union Catalog of the OLCC, the construction of the China National Bibliography Portal system was launched in 2012.

The collection principle of China National Bibliography is "refusing to confine within one territory or language", and the scope of the collection gradually extends from Chinese publications to those of other countries that study China and works published abroad by Chinese people, including the bibliographic data and collection data of general Chinese books, books in languages of ethnic minorities, serials, audio-visual materials, electronic publications, Braille reading materials (when necessary), various foreign language documents published in China, books published in Taiwan, Hong Kong, Macao and overseas, dissertations, Chinese materials (when necessary), western books on Chinese studies (when necessary), digital publications (when necessary), etc. At present, the China National Bibliography Portal has released the China National Bibliography for 2010-2019, which includes the resources of books, periodicals, newspapers, audiovisual electronic resources and doctoral dissertations published in China during 2010-2019. With the gradual expansion of the OLCC database and the development of the China National Bibliography Portal, a comprehensive database of the China National Bibliography with a larger scale, more varieties, wider coverage and more diversified service products has been formed.

New factors - the birth of linked data, the vigorous development of big data, the official adoption of Resource Description and Access (RDA) in the library community, and the complete release of the new model of the bibliographic framework aiming to replace MARC - add new momentum to the construction and development of the national bibliography. China National Bibliography has expanded from a traditional single bibliographic description of printed publications or physical publications to a three-dimensional display of the integration of books, scanned copies, table of contents and full text covering a variety of document types, carrier forms and languages (Mao, 2017). China National Bibliography has made a great move to provide FRBR services, and has conducted research and application of RDA on the theoretical and practical levels.

\section{Application research on the FRBRized displays of China National Bibliography}

\subsection{The FRBRized displays of China National Bibliography}

Since the birth of FRBR, IFLA has been actively advocating its application, and the library field is constantly exploring its application. In terms of catalogs, the FRBRization of library catalogs are mostly focused on, the aim of which is to enhance the bibliographic inquiry, retrieval and presentation in libraries, as well as to strengthen the bibliographic relationships between existing catalogs. One of FRBR's functions is to recommend a basic level of functionality and basic data requirements for records created by national bibliographic agencies. If the massive bibliographic data of China National Bibliography was re-cataloged according to the FRBR framework, it would cost a lot of time and resources, which is obviously not a good option for the library. To fulfill the goals of FRBR, one alternative and feasible approach is to identify FRBR entities and their relationships, and then carry out FRBRization.

With a huge amount of data and an integrated catalog, China National Bibliography hits the quality standard. Many collections are different manifestations of the same work with the same expression, or the different manifestations of the same original work with different expressions, thus the aggregate of bibliographic records could be better displayed after FRBRization. Therefore, the NLC launched the Research on the FRBRized Displays of China National Bibliography program from 2012 to 2015. 
Before the FRBRization of China National Bibliography, an experiment on the bibliographic aggregation was conducted on a small scale. Based on the Chinese and foreign language databases of the OLCC of China, bibliographic data of the classic book Dream of the Red Chamber with variant titles were extracted for two purposes. On the one hand, on the basis of the descriptions of Dream of the Red Chamber, following the definitions and attributes of work and expression defined in FRBR, a criterion to distinguish works from expressions was expected to be given. On the other hand, it was hoped that the difficulties in the FRBRization of existing data would be found, so rules for optimizing and improving data cataloging could be formulated for future work. During the experiment, by improving relevant authority records and depicting the relationships between and among the three entities, the data were structured and standardized in the Primo system, the mapping relationships among the data were formulated, and clustering algorithm rules and procedures for the FRBRization were especially developed.

The FRBRized displays of China National Bibliography have the following achievements (Mao et al., 2018, p. 127-128):

(a) The aggregation of the various editions, language versions, and carriers of the same work;

(b) The aggregation of the serial publications, including yearbooks;

(c) The aggregation of multiple-volume sets of the same publishing house; kind;

(d)The aggregation of periodicals of the same

(e) The re-aggregation of the series;

(f) The associative retrieval of accompanying materials;

(g) The ranked aggregation of records based on subject, publication date, etc.

Up to now, we have completed the FRBRized aggregation of the data of books, periodicals, newspapers and audio-visual electronic resources published in Chinese mainland, the data of yearbooks after 1949 and the doctoral dissertations from 2010 to 2019 collected in the NLC. In general, the China National Bibliography system played a better role of bibliographic records, helped users save retrieval time and provided a much better experience than using the common OPAC system.

\subsection{Difficulties and implications of the FRBRization of China National Bibliography}

The FRBRization of China National Bibliography improves the accuracy of bibliographic descriptions and user-friendliness, which to a certain extent facilitates the readers' use. However, it has been found that the FRBRization of the existing MARC data cannot realize all the ideas that FRBR creates. The MARC formats are designed far from the entity-relationship model. Based on the existing cataloging rules, some intellectual elements are neither described in the cataloged data nor structured ones, so it is difficult to realize the aggregation of related works only by re-processing the data.

\subsubsection{Problems with distinguishing between works and content expressions}

In the FRBR model, it is not clearly clarified how to identify a certain entity as a new work or a new expression of the original work, which affects the actual processing effect. In the batch processing of bibliographic records, it was found that many works cannot be recognized by the computers due to inconsistent descriptions in such areas as author items, literary genres, and so on. Therefore, manual intervention is needed to realize the aggregation of the works and expressions. Besides, different catalogers may have different understandings of the same material, so the processing of different catalogers might generate different results. Moreover, many manifestations contain multiple expressions/works. Since there is no clear criterion to follow in the FRBR model to identify works as well as to aggregate related works, a feasible logical algorithm could only be developed after manual judgment of a large amount of sample data.

\subsubsection{Problems with the structure of biblio- graphic and authority data}

Some fields or subfields of existing MARC records may present the attributes of multiple entities, and some note fields are often described in a casual way, lacking necessary structures. As a result, a lot of FRBR conceptual information cannot be extracted automatically by the computer. Both the existing bibliographic and authority records have the problem that some information is not described in a structured way. Therefore, the structured processing of data is not only the point that the future bibliographic format standards should focus on, but also should be given sufficient attention to in the cataloging rules (Zhu, 2017).

\subsubsection{Problems with the standardization of bibliographic and authority data}

One of the factors constraining the FRBRization of China National Bibliography is the standardization of the data. In addition to challenges with the cataloging quality and consistency of the bibliographic and authority data, issues with the standardization of the data are also reflected in the following three aspects: first, authority control is not implemented in some key access points, like titles and author items; second, cross-language name authority control is not adopted; finally, there are 
discrepancies between specific cataloging regulations. These hard nuts to be cracked often lead to a lot of troubles. For example, the same works might not be aggregated, because the name authority control or title authority control is not fully implemented, or as a result of discrepancies between specific cataloging regulations.

Therefore, besides fulfilling the basic functions of China National Bibliography, it is also necessary to consider how to evaluate and improve the effectiveness and adaptability of existing information organization rules and methods through bibliographic construction, how to optimize the existing cataloging regulations, standards and workflow, how to promote the authority control of bibliographic data, and how to add value to the data, all of which would help China National Bibliography become the core of knowledge organization and service network.

\section{Research on the feasibility of adopting RDA in China National Bibliography}

\subsection{The adoption of localized RDA in cataloging foreign language literature}

From the point of view of international bibliography development, RDA based on FRBR and correlation model is a trend of the field. China National Bibliography also actively follows the RDA framework. In April 2014, the translation of RDA into Chinese was published.

Internationally, cataloging agencies mostly adopt an integrated construction model of catalog, which means the bibliographic data in all languages and all carriers are compiled in one database, following the same cataloging rules and methods, to achieve an integrated management. However, in China, Chinese and foreign language bibliography follows different cataloging rules, thus forming a discrete cataloging system. Such system is caused by the complexity of the cataloging environment in China. Hence the development of localized RDA in China must take the following into consideration: (1) whether maintain the discrete cataloging model or take this opportunity to turn the Chinese and foreign language bibliography into the direction of an integrated system; (2) whether the Chinese bibliography adopts RDA rules completely or absorbs the advanced concepts of RDA and reconstructs Chinese cataloging rules according to its ideas. There is no unanimous answer to these questions in the Chinese cataloging community, and the integration of Chinese and foreign language literature cataloging cannot be achieved in a short term.

The NLC has finally decided that the localization of RDA is based on the principle of "foreign language literature cataloging first". That is to say, the RDA implementation will start with the foreign language literature cataloging since it is in line with the international practices, on the basis of which the RDA-based adaption of Chinese literature cataloging rules will be likely carried out. Nonetheless, it is not practical to apply RDA directly to the foreign language literature cataloging now. The flexibility of the RDA rules requires all countries to formulate more directive specifications in their local policy statements. The numerous optional clauses need to be clearly defined, the description level of the data needs to be determined, and the complex clauses need to be interpreted locally. In March 2017, the NLC announced the official adoption of RDA rules in the cataloging of all foreign language resources and completed the compilation of the National Library of China Policy Statements (Foreign Language Resources). On January 1, 2018, RDA was officially adopted in all cataloging work in the Foreign Language Publications Acquisitions \& Cataloging Department of NLC.

In order to test the compatibility and applicability of the National Library of China Policy Statements (Foreign Language Resources) in the cataloging practices, the NLC carried out application and technical tests. The former aimed to see the enforceability of the rules, including economic cost and individual experience, namely, whether the implementation of RDA would bring about a surge in cataloging costs in such aspects as time and manpower; whether catalogers accept the localized RDA rules and whether they can grasp the essence of its main idea as soon as possible through effective training, so as to quickly enhance the efficiency of work. Meanwhile, the key point of the technical test is to propose the technical requirements for the RDA-based transformation of the Aleph 500 system used for cataloging in the NLC. The testing results show that both objective data on cataloging costs and the subjective experience of catalogers positively support the implementation of $\mathrm{RDA}$, and that the cost increase resulting from the adoption of $\mathrm{RDA}$ in cataloging is within manageable limits (Cataloging..., 2017, p. 3). Most of the technical requirements can be met through system modifications, and RDA-based modifications can improve the users' experience of the OPAC system.

\subsection{The feasibility of RDA implementation in cataloging Chinese literature}

In 2016, the NLC specially conducted a survey on the feasibility of adopting RDA in cataloging Chinese literature. Based on a comparative study of RDA and the Chinese cataloging rules, the survey found that although there are some differences between them, and the CNMARC format used for cataloging Chinese literature needs modifications to be more compatible with RDA, there is no vast gulf between the two cataloging rules. The RDA-based adaption of Chinese literature cataloging rules is feasible in theory, but it needs to be postponed, as a lot 
of problems still need to be resolved both theoretically and practically.

(1) To get adapted to RDA rules, the current Chinese national standard "Resource Description" and the CNMARC standards need to be improved. The relevant cataloging work can only be carried out after the implementation specifications of relevant standards are determined.

(2) Considering the RDA rules generally mean what you get is what you see, and many description items are directly coming from the objective status of the publishing link, the workload will undoubtedly increase, if we completely rely on the manual operation of catalogers. Some countries like the United States that has implemented RDA by using the metadata in upstream publishing links, made their library rules adapted to the metadata collected to save the human costs. Therefore, if the RDA rules are adopted in the Chinese literature cataloging, it is necessary to accelerate the collaborative sharing of data with upstream publishers.

(3) In the context of union catalog, the data of China National Bibliography has been downloaded nearly 10 million times each year. Therefore, the implementation of RDA in Chinese literature cataloging is not a matter of the NLC alone. Both the staff and the system reserve ability of the member libraries under the OLCC of China should be taken into account.

(4) Since RDA rules would add new data elements, a corresponding library catalog system is needed to reveal them, in order to reflect the advantages of the RDA rules. The Aleph 500 system currently used in the NLC cannot fully support the display of the data based on RDA. If new rules are to be implemented, the upgrading of the integrated library system would be considered simultaneously.

(5) One of the major advantages of RDA rules is that the application of the rules becomes very flexible through the toolkit, and at the same time, it also provides a lot of online normative element forms, which are helpful for improving work efficiency and data standardization. If RDA rules are used in Chinese cataloging, it is necessary to develop the corresponding online toolkit, and formulate the cataloging workflow of each document type as well, which can be used by catalogers in practice to improve their efficiency.

For cataloging, the change of rules means the increase of all kinds of costs, such as historical data modification, system renovation, personnel training and so on. Although the idea of RDA has some significance for promoting bibliographic data interconnection and resource sharing, many of its rules are more suitable for that of western publications, and there are still many areas to be modified for its application with Chinese publications. Moreover, RDA rules mainly introduce certain elements to be taken to describe and distinguish resources, the localized rules are also very flexible in each country, and the same RDA is actually very different. Therefore, to get Chinese data across the world, it is necessary to combine the characteristics of Chinese publications and refine the specific operating rules in the case of applying the basic principles of RDA. At present, the conditions for implementing RDA in Chinese literature cataloging are not yet available, be it in terms of RDA, MARC format, system or personnel, and there is still a long way to go before the NLC announces the implementation of RDA in Chinese literature cataloging.

\section{Conclusion}

Relying on the OLCC of China, and taking the cataloging power of more than 2000 public libraries in China, the construction of China National Bibliography has been successfully carried out over years with great achievements. Under the national strategy of building China into a strong cyberpower and smart country, in 2020, the NLC organized the drafting of the Outline of the 14th Five-year Plan of the National Library of China, and formulated the latest development strategy of NLC, including researches on the construction of a multi-dimensional collection resource system, enhancing the collection quality of foreign literature resources, and the construction of a national digital network information acquisition and storage system covering the whole country, which are all instructive for improving the national bibliography in both depth and width in the new era. On the other hand, the theories and technologies of knowledge organization, data mining, semantic association, visual display and other fields are constantly developing, and provide a more effective way and platform for the integration, association and disclosure of bibliography. In the future, along the path of building the China National Bibliography we will also strengthen the researches on bibliography service mode, service experience, service efficiency and service innovation, so as to make contribution to the development of librarianship. 


\section{References}

Cataloging Committee of the National Library of China (2017) National Library of China RDA Policy Statements (Foreign Language Resources). Beijing: Nat. Libr. of China Publ. House.

Chen Ch, Ke P and Liu Zh (1984) The national bibliography of our country for the recent 35 years. Wuhan University Journal (Humanity Sciences) 6: 112-117.

Huang J (1986) Review and prospects of the China National Bibliography. Library Theory and Practice 1: 3-8.
Mao Y (2017) Reviews and consideration on construction of the China National Bibliography. Researches in Library Science 14: 45-49.

Mao Ya et al. (2018) Construction of the China National Bibliography in Digital Era and Its FRBRization Service. Beijing: Nat. Libr. of China Publ. House.

National Library of China (2020) General Bibliography on the Minguo Period. Vol. Natural Science (Basic Science). Beijing: Nat. Libr. of China Publ. House.

Zhu Q (2017) Research on FRBRization application status and strategies in the cataloging process. Library Journal 37 (2): 4655. 